\title{
Strategi Pengembangan Komoditas Pangan Menuju Ketahanan Pangan Nasional Dengan Pendekatan SWOT-ISM-BSC
}

\author{
Agus Herjito ${ }^{1^{*}}$, Daniel Setiawan ${ }^{1}$ \\ Sekolah Staf dan Komando Angkatan Laut (SESKOAL) \\ Jl. Ciledug Raya No 2, Kompleks Seskoal Kebayoran Lama Kota Jakarta \\ *agusherjitoseskoal@gmail.com \\ DOI: https://doi.org/10.21107/rekayasa.v14i2.10864
}

\begin{abstract}
Sampai saat ini Ketahanan Pangan Nasional Indonesia masih berada pada kondisi yang belum stabil. Kondisi ini memberikan gambaran nyata bahwa ada permasalahan yang dialami bangsa Indonesia di bidang ketahanan pangan. Karena pada posisi keberadaan wilayah Indonesia yang sangat strategis maka semestinya Indonesia menjadi bangsa dan negara yang makmur dan mandiri dalam hal sumber pangan. Penelitian ini bertujuan untuk mengembangan strategi kebijakan pengembangan komoditas pangan menuju ketahanan pangan nasional. Dalam mendukung penelitian ini digunakan metode SWOT, Interpretative Structural Modeling (ISM), dan Balanced Score Card (BSC). Metode SWOT digunakan untuk merumuskan strategi berdasarkan identifikasi faktor internal dan faktor eksternal yang berpengaruh signifikan berbasis model Mckinsey 7S dan PEST. Selanjutnya metode ISM digunakan untuk menentukan prioritas strategi. Metode BSC digunakan untuk menentukan rencana implementasi dan pemetaan dari strategi-strategi yang dirumuskan. Pengembangan strategi kebijakan pengembangan komoditas pangan menuju ketahanan pangan nasional berdasarkan hasil penelitian terdiri dari 10 (sepuluh) strategi utama yang terdiri dari Strategi SO-1,2,3, Strategi WO-1,2,3, Strategi ST1,2,3 dan Strategi WT-1. Diharapkan kesepuluh strategi hasil penelitian ini dapat meningkatkan pengembangan komoditas pangan Indonesia menuju Ketahanan Pangan Nasional yang stabil dan sustainable.
\end{abstract}

Keyword: komoditas pangan, SWOT, Interpretative Structural Modeling (ISM), Balanced Score Card (BSC)

\section{PENDAHULUAN}

Salah satu bidang ketahanan nasional yang cukup penting adalah ketahanan nasional di bidang ekonomi. Dalam hal penguatan ketahanan nasional bidang ekonomi dan penguatan daya saing nasional, minimal ada 4 (empat) sektor prioritas kebijakan, yaitu: 1) Sektor kemandirian pangan atau ketahanan pangan; 2) Ketersediaan sumber daya energi untuk kebijakan industrialisasi di berbagai sektor; 3) Kebijakan percepatan pembangunan infrastruktur fisik dan non fisik; 4) Kebijakan penguatan di sektor keuangan.

Sektor pangan nasional saat ini masih memiliki kendala yang mempengaruhi ketahanan pangan nasional, antara lain kondisi riil dimana sejak tahun 2004 Indonesia telah menyandang status sebagai net importer pangan. Kondisi net importer ini dilakukan untuk memenuhi konsumsi pangan domestik yang tidak dapat dicukupi oleh produksi

\section{Article History:}

Received: June 16 $6^{\text {th }}$ 2021; Accepted: July, 25 2021

Rekayasa ISSN: $2502-5325$ has been Accredited by Ristekdikti (Arjuna) Decree: No. 23/E/KPT/2019 August 8th, 2019 effective until 2023 pangan dalam negeri. Upaya pemerintah yang dilakukan adalah dengan memaksimasi inflow devisa dan meminimasi outflow devisa dalam hubungannya dengan revitalisasi komoditas pangan. Berdasarkan kondisi tersebut, maka penelitian ini bertujuan untuk menyusun suatu strategi kebijakan dalam rangka pengembangan komoditas pangan menuju ketahanan pangan nasional Indonesia. Dalam mendukung penelitian ini, digunakan metode analisis strategi SWOT, Interpretative Structural Modeling (ISM), dan Balanced Score Card (BSC). Metode SWOT digunakan untuk merumuskan strategi berdasarkan faktor internal dan faktor eksternal yang berpengaruh pada aspek ketahanan pangan. Metode ISM digunakan untuk menentukan prioritas sub strategi. Metode BSC digunakan untuk

\section{Cite this as:}

Herjito, A \& Setiawan, D. (2021). Strategi Pengembangan Komoditas Pangan Menuju Ketahanan Pangan Nasional dengan Pendekatan SWOT-ISM-BSC. Rekayasa 14 (2). 159-167. doi: https://doi.org/10.21107/rekayasa.v14i2.10864

(c) 2021 Agus Herjito \& Daniel Setiawan 
menentukan rencana implementasi dan pemetaan dari strategi dan sub strategi yang dirumuskan.

Terdapat beberapa penelitian terdahulu sebagai referensi dalam hal pengembangan metode strategi, antara lain penelitian Reliability-Centered Maintenance (RCM) berbasis SWOT-ISM (Gupta, et al., 2018; Zadeh, et al., 2018; Živković, et al., 2015; Czajkowska, 2016). Penelitian lain yang sejenis tentang pemetaan strategi berdasarkan metode ISM dan Balanced Scorecard, antara lain oleh Roy \& Misra (2016), Rizal, et al (2016), Panackal \& Singh (2016), Jafari, et al (2015) dan Iranzadeh, et al (2017).

Selanjutnya penelitian ini, lebih difokuskan pada penyusunan strategi pengembangan dan pengelolaan komoditas pangan nasional secara umum, sehingga diharapkan dapat memenuhi kebutuhan pangan nasional secara mandiri. Penelitian ini diharapkan (1) Mampu membantu tujuan pemerintah dalam meminimasi net importer dan defisit transaksi berjalan/Current Account Deficit (CAD), (2) Penelitian ini juga diharapkan dapat meningkatkan kualitas keberlanjutan implementasi mandatori komoditas pangan serta pengembangannya.

\section{METODE PENELITIAN}

\section{Konsep Analisis Mckinsey 7S}

Konsep McKInsey adalah sebuah konsep model manajemen yang menguraikan 7 aspek untuk mengorganisasi sebuah organisasi dengan cara yang efektif dan menyeluruh. Semua faktor ini secara bersama-sama menentukan sebuah korporasi beroperasi. tujuh aspek berpengaruh terhadap kesuksesan suatu organisasi yang terangkum dalm 7-S McKinsey, yaitu Strategi dan struktur (hardware of organization) serta style (gaya), system, staff (karyawan), skills (kemampuan), dan shared values (budaya organisasi) yang merupakan software of organization. Alat Analisis tersebut dikenal sebagai model The Seven SMcKinsey.

Tabel 1. Analisis Faktor pada Kerangka Kerja Mckinsey 75

\begin{tabular}{|c|c|c|}
\hline No & Mckinsey Criteria & Analysis Factors \\
\hline 1 & Strategy & $\begin{array}{l}\text { Strategic Planning } \\
\text { Vision and Mission }\end{array}$ \\
\hline 2 & Structure & Organization \\
\hline 3 & System & $\begin{array}{l}\text { Technology } \\
\text { Platform Support }\end{array}$ \\
\hline 4 & Staff & $\begin{array}{l}\text { Workforce Management } \\
\text { Project Team }\end{array}$ \\
\hline 5 & Skill & Management Skill \\
\hline 6 & Style & Leadership \\
\hline
\end{tabular}

\begin{tabular}{lll}
\hline No & Mckinsey Criteria & Analysis Factors \\
\hline & & Communication \\
7 & Shared Values & Productivity; Trust \\
\hline
\end{tabular}

\section{Analisis PEST}

Arah analisis PEST adalah kerangka berfikir untuk menilai beberapa situasi, dan menilai beberapa strategi dan posisi, arah perencanaan, strategi market atau ide pengembangan. Faktor analisis PEST sangat berperan penting dalam menciptakan suatu nilai keuntungan dari beberapa strategi yang terjadi di luar kontrol sebuah manajemen dan secara normal harus mempertimbangkan ancaman, kerugian, peluang dan keuntungan. PEST digunakan sebagai integrasi model seven stroke strategy. PEST digunakan sebagai analisis faktor eksternal pada green job. PEST digunakan untuk menyajikan fuzzy decision map. PEST digunakan untuk mengidentifikasi kriteria pada pertanyaan penelitian sistem informasi.

Tabel 2. Analisis PEST pada Pengembangan Strategi Ketahanan Pangan Nasional

\begin{tabular}{lll}
\hline No & PEST Criteria & Factor analysis \\
\hline 1 & Political & $\begin{array}{l}\text { Government policy } \\
\text { Policy }\end{array}$ \\
& & $\begin{array}{l}\text { Economic Growth } \\
\text { Natural Resources } \\
\text { Human resources } \\
\text { Culture }\end{array}$ \\
& Economic & Technology Development \\
& & Technology Transfer \\
\hline
\end{tabular}

Sumber: (Alshaher, 2013)

\section{Analisis SWOT}

Analisis SWOT adalah analisis suatu kondisi internal maupun eksternal dari organisasi yang akan digunakan sebagai dasar untuk merancang strategi perencanaan dan program kerja.

Tabel 3. Analisis Matriks SWOT

\begin{tabular}{lcc} 
& \multicolumn{2}{c}{ Faktor Eksternal } \\
SWOT Analysis & Opportunity & Threat (T) \\
& $(0)$ &
\end{tabular}

\begin{tabular}{llcc}
\hline $\begin{array}{l}\text { Faktor } \\
\text { Internal }\end{array}$ & $\begin{array}{l}\text { Strength } \\
\text { (S) }\end{array}$ & SO Strategy & ST Strategy \\
& $\begin{array}{l}\text { Weakness } \\
\text { (W) }\end{array}$ & WO Strategy & WT \\
& & Strategy \\
\hline
\end{tabular}

Analisis internal meliputi penilaian terhadap faktor kekuatan (Strength) dan faktor kelemahan (Weakness). Sementara, analisis eksternal mencakup analisis faktor peluang (Opportunity) dan analisis tantangan (Threath). 


\section{Interpretative Structural Modeling (ISM)}

Interpretative Structural Modeling (ISM), adalah suatu teknik yang digunakan dalam permodelan yang mampu mensinkronisasi pendapat para ahli dalam memberikan gambaran yang konkrit tentang struktur hirarki sub-elemen dari setiap elemen sistem, dan dalam menemukan sub-elemen kunci serta karakter setiap sub-elemen, sebagai basis pengetahuan yang bermanfaat untuk menyusun perencanaan strategi pengembangan agroindustri yang terpadu dan lintas sektor. Teknik ISM ini dapat digunakan untuk melakukan analisis program yang sesuai dengan visi dan misi. Secara garis besar teknik ISM dibagi menjadi dua bagian, yaitu: klasifikasi elemen dan penyusunan hirarki.

Langkah pertama yang perlu dilakukan dalam analisis ISM adalah menentukan elemen-elemen yang sesuai dengan permasalahan yang ada. Selanjutnya disusun sub-elemen pada setiap elemen yang terpilih. Pemilihan elemen dan penyusunan sub elemen dilakukan dari hasil diskusi dengan pakar. Hasil penilaian tersebut tersusun dalam Structural Self Interaction Matrix (SSIM) yang dibuat dalam bentuk tabel Rechability Matrix (RM) dengan mengganti $\mathrm{V}, \mathrm{A}, \mathrm{X}, \mathrm{O}$ menjadi bilangan 1 dan 0. Klasifikasi elemen didasarkan pada Structural Self Matrix (SSM) yang dibuat berdasarkan sistem VAXO, yaitu :

$$
\begin{aligned}
& \vee \text { jika eij }=1 \text { dan eji }=0 ; \\
& \text { A jika eij }=0 \text { dan eji }=1 ; \\
& \text { X jika eij }=1 \text { dan eji }=1 ; \\
& \text { O jika eij }=0 \text { dan eji }=0
\end{aligned}
$$

Matrik kemudian dirubah menjadi matrik tertutup. Hal ini dilakukan untuk mengoreksi matriks tersebut memenuhi kaidah transitivity yaitu jika A mempengaruhi $B$ dan $B$ mempengaruhi $C$, maka $A$ harus mempengaruhi $C$. Nilai 1 berarti ada hubungan kontekstual antara elemen ke -i dan elemen ke-j, sedangkan eij $=0$ berarti tidak ada hubungan kontekstual antar elemen ke-i dengan elemen ke-j. Kemudian SSM diubah menjadi reachability matrix dengan merubah VAXO menjadi 1 dan 0 , selanjutnya dilakukan pengujian terhadap aturan transivity, sampai terjadi matrik yang tertutup. Matrik yang telah memenuhi transivity dilanjutkan pengolahannya untuk mendapatkan matrik reachability, untuk mendapatkan Driver Power (DP) dan Depedence (D).

\section{Analisis Balanced Score Card (BSC)}

Balanced Score Card adalah sistem manajemen kinerja terintegrasi yang menghubungkan berbagai tujuan dan ukuran kinerja dan strategi organisasi.
Balanced Scorecard menerjemahkan misi dan strategi organisasi dalam tujuan operasional dan ukuran kinerja dalam empat perspektif, yaitu perspektif keuangan, perspektif pelanggan, perspektif proses bisnis internal, serta perspektif pembelajaran dan pertumbuhan. Konsep ini memperkenalkan suatu sistem pengukuran kinerja perusahaan dengan menggunakan kriteria-kriteria tertentu. Kriteria tersebut sebenarnya merupakan penjabaran dari apa yang menjadi misi dan strategi perusahaan dalam jangka panjang, yang digolongkan menjadi empat perspektif yang berbeda yaitu :

1. Perspektif Finansial

Orientasi pada pencapaian keuangan organisasi yang stabil.

2. Perspektif Customer

Orientasi menjadi supplier bernilai bagi customer.

3. Perspektif Proses Bisnis Internal

Proses bisnis apa saja yang terbaik yang dilakukan baik jangka panjang maupun jangka pendek untuk mencapai finansial dan kepuasan customer.

4. Perspektif Pertumbuhan dan Pembelajaran Peningkatan dengan menciptakan nilai secara terus menerus, terutama hubungannya dengan kemampuan dan motivasi personel organisasi.

\section{HASIL DAN PEMBAHASAN Analisis SWOT Faktor Eksternal}

Analisis lingkungan eksternal mengindikasikan peluang dan ancaman yang dihadapi dalam pengembangan bahan bakar komoditas pangan. analisis ini menyediakan informasi yang menyeluruh tentang kondisi eksternal untuk digunakan sebagai salah satu bentuk masukan dalam bentuk proses perencanaan strategi pengembangan komoditas pangan. Untuk menganalisis faktor ekternal digunakan model analisis PEST (Politik, Ekonomi, Sosial dan Teknologi). Dalam analisis PEST terdapat delapan analisis faktor yang mempengaruhi kondisi eksternal (Tabel 4). 
Tabel 4. Analisis Faktor Eksternal

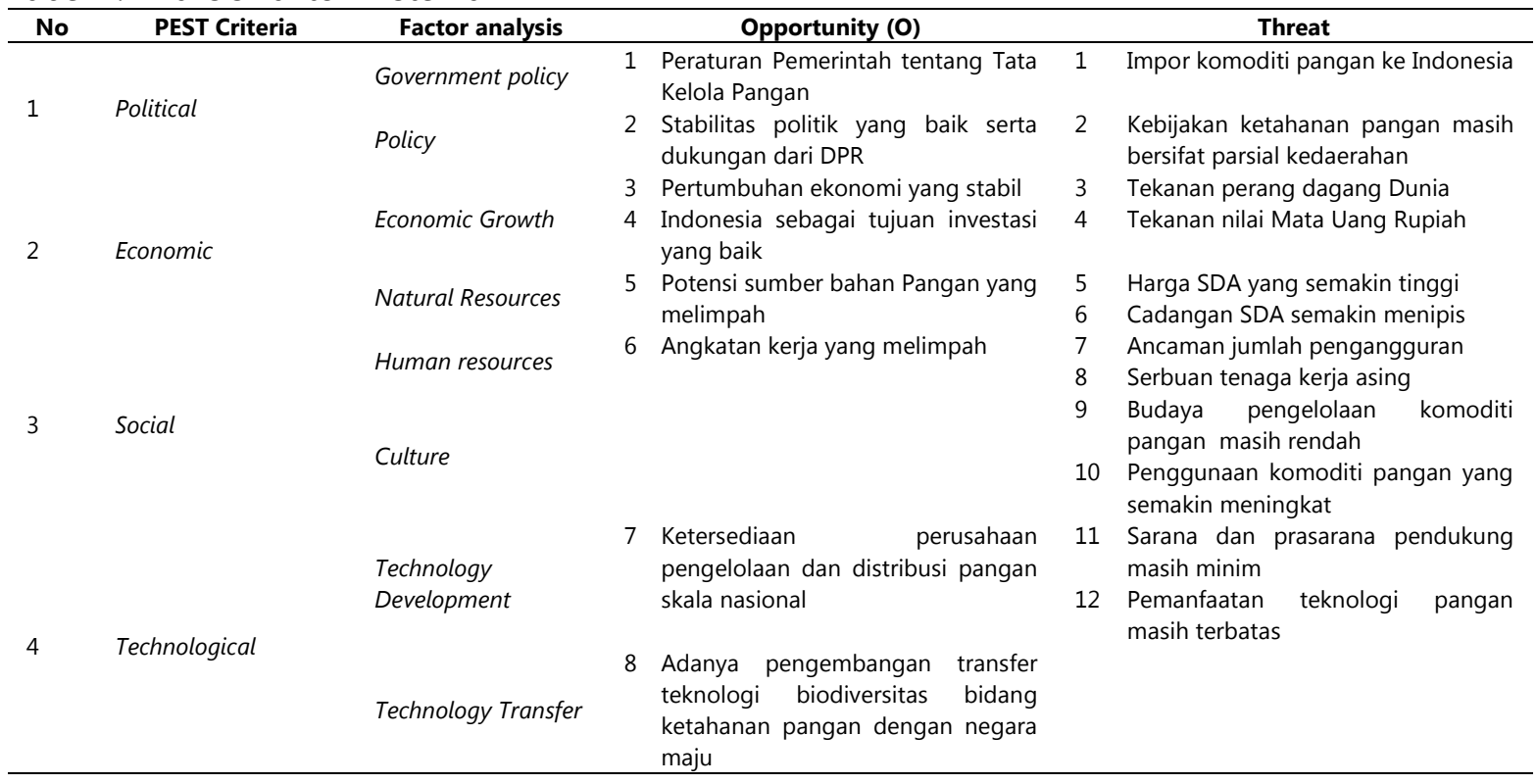

Tabel 5. Analisis faktor Internal

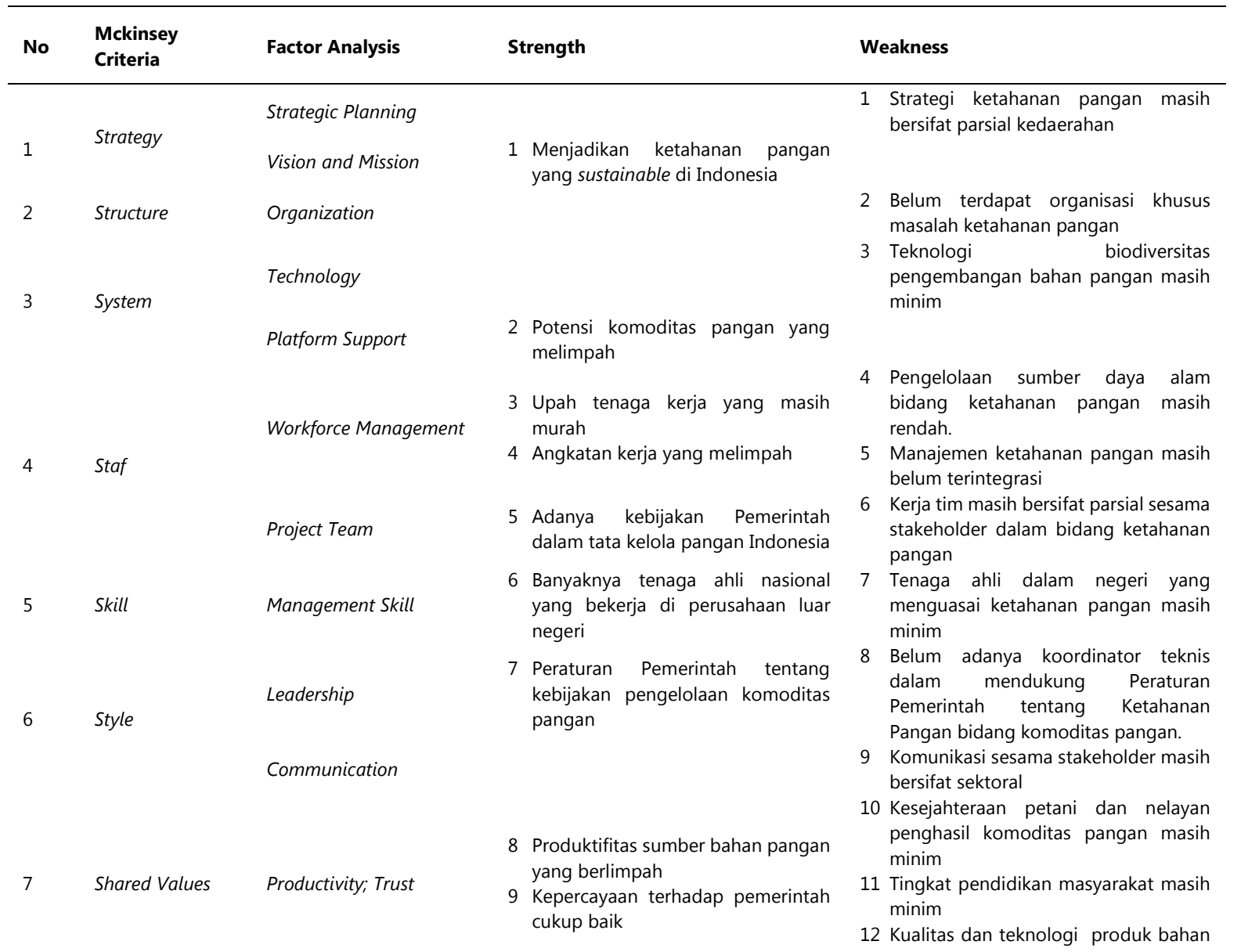

\section{Analisis SWOT Faktor Internal}

Analisis terhadap lingkungan internal bertujuan untuk mengidentifikasi sejumlah kekuatan dan kelemahan yang terdapat pada sumber daya dan proses bisnis internal yang dimiliki (Tabel 5). Dalam strategi pengembangan pangan komoditas pangan, analisis faktor internal digunakan untuk mengindentifikasi kekuatan dan kelemahan dalam membangun ketahanan pangan nasional. 
Tabel 5. Analisis Matriks SWOT (SO-ST)

\begin{tabular}{|c|c|}
\hline Strenght (S) & Opportunity (0) \\
\hline
\end{tabular}

Tabel 6. Analisis Matriks SWOT (WO-WT)

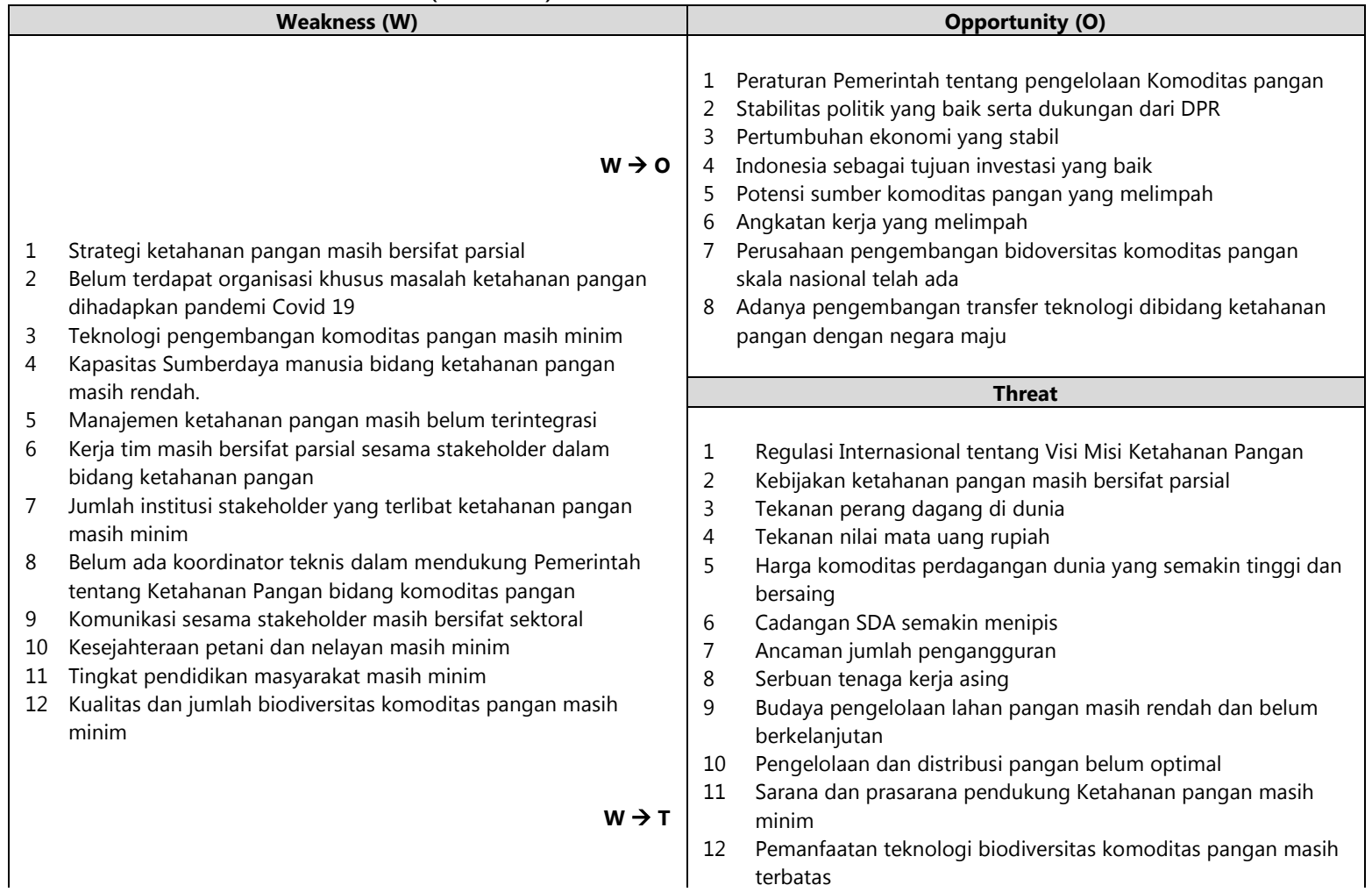

Berdasarkan identifikasi dari berbagai faktor internal dan eksternal maka langkah selanjutnya dapat disusun faktor-faktor strategi (Tabel 6 dan Tabel 7). Dari faktor internal dan eksternal yang ada kemudian dipadukan untuk menentukan alternatif strategi pengembangan ketahanan pangan komoditas pangan. Berikut stategi yang dirumuskan dan dihasilkan dari matriks SWOT (Tabel 8). 
Tabel 8. Perumusan Strategi Pengembangan Komoditi Pangan Nasional

\begin{tabular}{|c|c|c|}
\hline$x$ & $S$ & $\mathbf{w}$ \\
\hline \multirow[b]{2}{*}{0} & Strategy S-O & Strategy W-O \\
\hline & $\begin{array}{l}\text { 1. Ekstensifikasi dan intensifikasi bidang Ketahanan } \\
\text { 2. Mangan Komoditas pangan. } \\
\text { Meningkatkan investasi dari luar dalam hal } \\
\text { ketahanan pangan komoditas pangan. } \\
\text { 3. Mengirim tenaga kerja dan kerjasama dengan } \\
\text { tenaga ahli dari luar negeri untuk transfer teknologi } \\
\text { komoditas pangan. }\end{array}$ & $\begin{array}{l}\text { 1. Membangun sinergitas sesama stakeholder } \\
\text { dibidang ketahanan pangan untuk peningkatan } \\
\text { komoditas pangan. } \\
\text { 2. Kerjasama dan pembangunan serta transfer } \\
\text { teknologi biodiversitas dibidang ketahanan } \\
\text { pangan untuk peningkatan komoditas pangan. } \\
\text { 3. Membentuk badan khusus sifatnya teknis dalam } \\
\text { menangani program ketahanan pangan untuk } \\
\text { peningkatan dan pengembangan komoditas } \\
\text { pangan. }\end{array}$ \\
\hline \multirow[b]{2}{*}{$\mathbf{T}$} & Strategy S-T & Strategy W-T \\
\hline & $\begin{array}{l}\text { 1. Pengelolaan distribusi komoditas pangan ke } \\
\text { daerah-daerah secara menyeluruh untuk konsumsi } \\
\text { dalam negeri sebagai bagian dari Ketahanan Pangan } \\
\text { Nasional } \\
\text { 2. Penguatan kebijakan pengelolaan dan produktivitas } \\
\text { komoditas pangan sebagai program utama } \\
\text { pemerintah. } \\
\text { 3. Pembangunan infrastruktur, sarana dan prasarana } \\
\text { serta peningkatan teknologi pangan komoditas } \\
\text { pangan. }\end{array}$ & $\begin{array}{l}\text { 1. Penyediaan infrastruktur dan tenaga ahli yang } \\
\text { sudah ada dalam mendukung kebijakan } \\
\text { komoditas pangan nasional. }\end{array}$ \\
\hline
\end{tabular}

Tabel 7. Kompilasi Strategi dari Analisis Matriks SWOT

\begin{tabular}{|c|c|}
\hline Code & Kompilasi Strategi \\
\hline SO-1 & Ekstensifikasi dan intensifikasi bidang ketahanan pangan komoditas pangan. \\
\hline SO-2 & Meningkatkan investasi dari luar dalam hal ketahanan pangan komoditas pangan. \\
\hline SO-3 & $\begin{array}{l}\text { Mengirim tenaga kerja dan kerjasama dengan tenaga ahli dari luar negeri untuk transfer teknologi komoditas } \\
\text { pangan. }\end{array}$ \\
\hline ST-1 & $\begin{array}{l}\text { Pengelolaan distribusi komoditas pangan ke daerah-daerah secara menyeluruh untuk konsumsi dalam negeri } \\
\text { sebagai bagian dari Ketahanan Pangan Nasional }\end{array}$ \\
\hline ST-2 & Penguatan kebijakan pengelolaan dan produktivitas komoditas pangan sebagai program utama pemerintah. \\
\hline ST-3 & $\begin{array}{l}\text { Pembangunan infrastruktur, sarana dan prasarana serta peningkatan teknologi pangan untuk peningkatan } \\
\text { komoditas pangan. }\end{array}$ \\
\hline WO-1 & $\begin{array}{l}\text { Membangun sinergitas sesama stakeholder dibidang ketahanan pangan untuk peningkatan komoditas } \\
\text { pangan. }\end{array}$ \\
\hline WO-2 & $\begin{array}{l}\text { Kerjasama dan pembangunan serta transfer teknologi biodiversitas dibidang ketahanan pangan untuk } \\
\text { peningkatan komoditas pangan. }\end{array}$ \\
\hline WO-3 & $\begin{array}{l}\text { Membentuk badan khusus yang sifatnya teknis dalam menangani program ketahanan pangan untuk } \\
\text { peningkatan dan pengembangan komoditas pangan. }\end{array}$ \\
\hline WT-1 & Penyediaan infrasturktur dan pemanfaatan tenaga ahli yang sudah ada dalam men \\
\hline
\end{tabular}

Berdasarkan hasil analisis matriks SWOT, Strategi SO, Strategi WO, Strategi ST, masingmasing terdiri dari tiga sub strategi. Sedangkan strategi WT terdiri dari satu sub strategi. Selanjutnya, seluruh langkah strategi tersebut akan dikompilasi menjadi satu sehingga didapatkan sepuluh sub strategi pengembangan pangan komoditas pangan (Tabel 9).

\section{Interpretative Structural Modeling (ISM).}

Penyusunan prioritas dan strategy mapping diawali dengan membentuk sistem hirarki antar aspek yang teridentifikasi sebelumnya. Pembentukan sistem hirarki dengan menggunakan pendekatan metode Interpretative Structural Modeling. Metode ini bertujuan untuk merencanakan strategi yang terpilih untuk diuraikan dalam rencana implementasi berdasarkan atas susunan hirarki. Dalam strategi pembangunan SSAT, didapat langkah-langkah metode ISM sebagai berikut. 
Tabel 8. SSIM pada Penelitian

\begin{tabular}{|l|l|l|l|l|l|l|l|l|l|l|l|}
\hline No & Kode & $\mathbf{1 0}$ & $\mathbf{9}$ & $\mathbf{8}$ & $\mathbf{7}$ & $\mathbf{6}$ & $\mathbf{5}$ & $\mathbf{4}$ & $\mathbf{3}$ & $\mathbf{2}$ & $\mathbf{1}$ \\
\hline $\mathbf{1}$ & SO-1 & X & A & X & A & X & A & V & A & A & - \\
\hline $\mathbf{2}$ & SO-2 & X & A & X & A & V & A & V & A & - & \\
\hline $\mathbf{3}$ & SO-3 & A & O & O & X & V & A & O & - & & \\
\hline $\mathbf{4}$ & ST-1 & O & A & A & O & O & X & - & & & \\
\hline $\mathbf{5}$ & ST-2 & A & O & O & V & A & - & & & & \\
\hline $\mathbf{6}$ & ST-3 & A & A & X & X & - & & & & & \\
\hline $\mathbf{7}$ & WO-1 & O & A & X & - & & & & & & \\
\hline $\mathbf{8}$ & WO-2 & V & A & - & & & & & & & \\
\hline $\mathbf{9}$ & WO-3 & O & - & & & & & & & & \\
\hline $\mathbf{1 0}$ & WT-1 & - & & & & & & & & & \\
\hline
\end{tabular}

Tabel 9. Reachability Matrix pada Penelitian

\begin{tabular}{|l|l|l|l|l|l|l|l|l|l|l|l|l|l|}
\hline No & Kode & $\mathbf{1}$ & $\mathbf{2}$ & $\mathbf{3}$ & $\mathbf{4}$ & $\mathbf{5}$ & $\mathbf{6}$ & $\mathbf{7}$ & $\mathbf{8}$ & $\mathbf{9}$ & $\mathbf{1 0}$ & DP & Level \\
\hline $\mathbf{1}$ & SO-1 & 0 & 1 & 0 & 1 & 0 & 1 & 1 & 0 & 0 & 0 & $\mathbf{4}$ & $\mathbf{4}$ \\
\hline $\mathbf{2}$ & SO-2 & 1 & 0 & 1 & 1 & 0 & 0 & 1 & 1 & 1 & 0 & $\mathbf{6}$ & $\mathbf{2}$ \\
\hline $\mathbf{3}$ & SO-3 & 1 & 0 & 1 & 1 & 1 & 0 & 0 & 0 & 1 & 0 & $\mathbf{5}$ & $\mathbf{3}$ \\
\hline $\mathbf{4}$ & ST-1 & 0 & 0 & 1 & 0 & 1 & 0 & 0 & 0 & 0 & 0 & $\mathbf{2}$ & $\mathbf{5}$ \\
\hline $\mathbf{5}$ & ST-2 & 1 & 0 & 1 & 0 & 1 & 0 & 1 & 1 & 1 & 0 & $\mathbf{6}$ & $\mathbf{2}$ \\
\hline $\mathbf{6}$ & ST-3 & 0 & 1 & 0 & 1 & 1 & 0 & 1 & 0 & 0 & 0 & $\mathbf{4}$ & $\mathbf{4}$ \\
\hline $\mathbf{7}$ & WO-1 & 1 & 0 & 1 & 0 & 0 & 1 & 1 & 1 & 0 & 0 & $\mathbf{5}$ & $\mathbf{3}$ \\
\hline $\mathbf{8}$ & WO-2 & 1 & 1 & 0 & 1 & 1 & 1 & 1 & 1 & 0 & 1 & $\mathbf{8}$ & $\mathbf{1}$ \\
\hline $\mathbf{9}$ & WO-3 & 1 & 0 & 1 & 1 & 0 & 1 & 1 & 1 & 1 & 1 & $\mathbf{8}$ & $\mathbf{1}$ \\
\hline $\mathbf{1 0}$ & WT-1 & 1 & 1 & 1 & 0 & 0 & 1 & 0 & 0 & 0 & 1 & $\mathbf{5}$ & $\mathbf{3}$ \\
\hline
\end{tabular}

\section{Structural Self Interaction Matrix (SSIM)}

SSIM merupakan tahapan untuk menentukan variabel-variabel yang dominan dari hasil analisis SWOT untuk mengetahui tingkat hubungan keterkaitan antar sub strategi (Tabel 10).

\section{Reachability Matrix (RM)}

Selanjutnya, berdasarkan tabel $x x$ tentang matrik SSIM selanjutnya dibuat dalam bentuk tabel Reachability Matrix (RM) dengan mengganti V, A, X, O menjadi bilangan 1 dan 0 (Tabel 11).

Struktur elemen di atas menunjukkan bahwa strategi WO-2 dan WO-3 berada pada Level prioritas 1; Strategi ST-2 dan SO-2 pada Level prioritas 2; Strategi SO-3, WO-1, dan WT-1 pada Level prioritas 3; Strategi ST-3 dan SO-1 pada Level prioritas 4; sedangkan Strategi ST-1 berada pada puncak Strategi sebagai level prioritas 5 .

\section{Peta dan Rencana Implementasi Strategi.}

Peta strategi menunjukkan gambar bagaimana setiap kinerja dapat mendukung pencapaian keseluruhan tujuan strategis organisasi. Peta strategi membantu organisasi terutama memvisualisasikan apa yang diperlukan untuk melakukan dan mendukung strategi pengembangan komoditas pangan sebagai pangan terbarukan dalam mendukung ketahanan nasional.
Peta strategi akan memberikan kemudahan bagi seluruh pelaku organisasi untuk memantau perkembangan implementasi strategi. Analisis hasil rancangan peta strategi menghubungkan Balanced Scorecard dengan strategi yang dirancang yaitu pengembangan pangan komoditas pangan dalam mendukung ketahanan pangan nasional.

Perspektif internal process terdiri dari 2 (dua) Sub Strategi yaitu 1) Pembentukan badan dalam menangani program ketahanan pangan nasional (WO-3); 2) Kerjasama dan pembangunan serta tranfer teknologi dibidang ketahanan pangan komoditas pangan (WO-2). Perspektif finansial terdiri dari 2 (dua) Sub Strategi yaitu 1) Meningkatkan investasi dari luar dalam hal ketahanan pangan komoditas pangan (SO-2); 2) Penguatan kebijakan penggunaan komoditas pangan sebagai program utama pemerintah pengganti minyak mentah (ST-2).

Perspektif Learning \& Growth (L\&G) terdiri dari 3 (tiga) Sub strategi, yaitu 1) Mengirim tenaga kerja dan menarik tenaga ahli dari luar negeri untuk kerjasama transfer teknologi komoditas pangan (SO-3); 2) Membangun sinergitas sesama stakeholder dibidang ketahanan pangan komoditas 


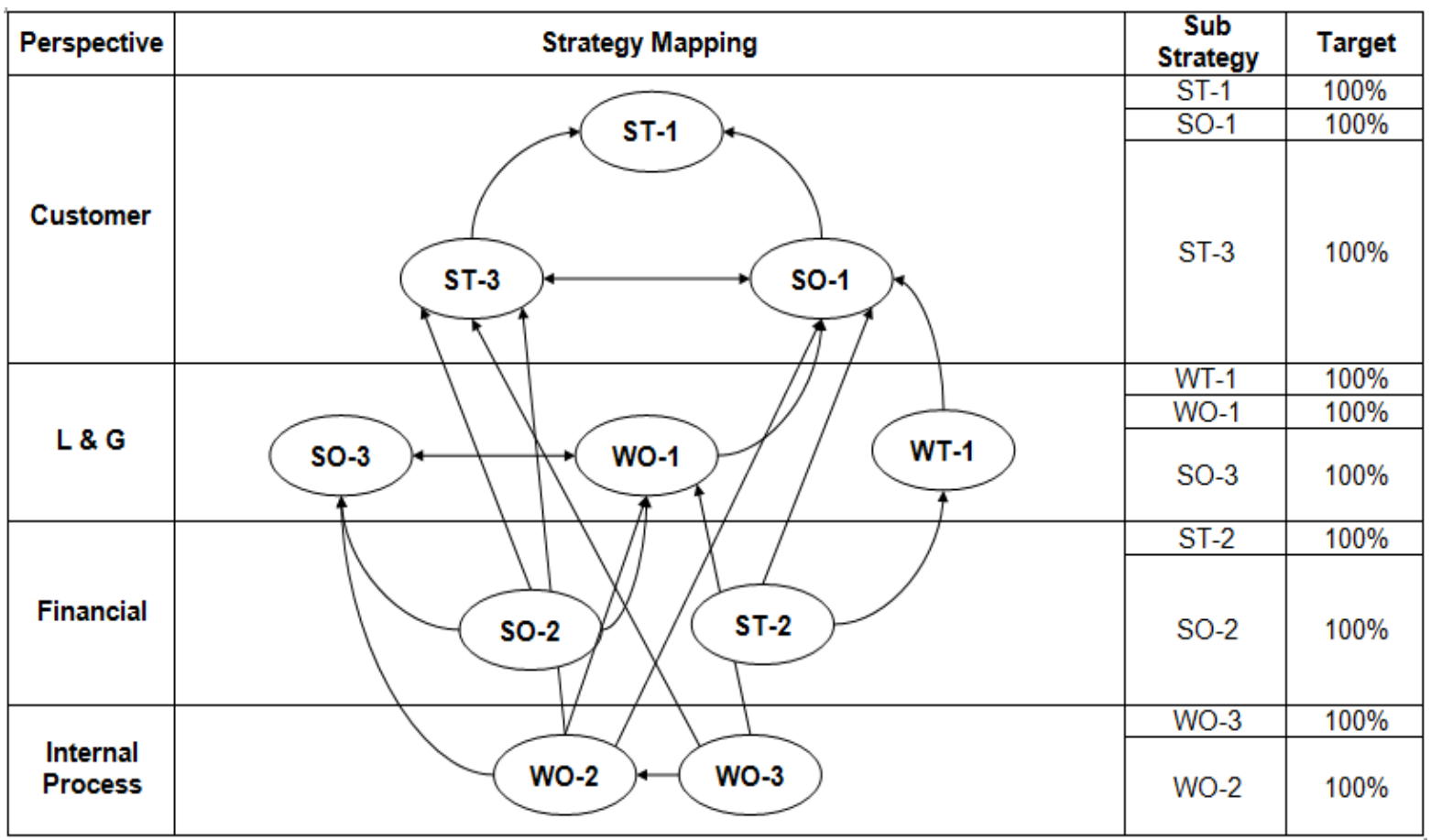

Gambar 1. Peta Strategi Pengembangan Komoditas Pangan

Menuju Ketahanan Pangan Nasional Indonesia

pangan (WO-1); 3) Memanfaatkan infrastuktur dan tenaga ahli yang sudah ada dalam mendukung kebijakan komoditas pangan nasional (WT-1). Perspektif Customer terdiri dari 3 (tiga) Sub strategi yaitu 1) Pembangunan infrastruktur, sarana dan prasarana serta peningkatan teknologi pangan komoditas pangan (ST-3); 2) Ekstensifikasi dan intensifikasi bidang ketahanan pangan komoditas pangan (SO-1); 3) Pemanfaatan pangan komoditas pangan untuk konsumsi dalam negeri sebagai bagian dari tekanan impor Eropa (ST-1).

\section{KESIMPULAN}

Pengembangan strategi kebijakan Komoditas pangan sebagai komoditas ketahanan pangan terbarukan berdasarkan hasil penelitian terdiri dari 10 (sepuluh) sub strategi yang terdiri dari Strategi SO, Strategi WO, Strategi ST, masing-masing terdiri dari tiga sub strategi. Sedangkan strategi WT terdiri dari satu sub strategi.

Pada aspek pemetaan strategi dan rencana implementasi strategi menunjukkan bahwa strategi WO-2 dan WO-3 berada pada Level prioritas 1; Strategi ST-2 dan SO-2 pada Level prioritas 2; Strategi SO-3, WO-1, dan WT-1 pada Level prioritas 3; Strategi ST-3 dan SO-1 pada Level prioritas 4; sedangkan Strategi ST-1 berada pada puncak Strategi sebagai level prioritas 5 .
Pada aspek rencana implementasi strategi berbasis balanced scorecard yaitu Perspektif internal proses terdiri dari 2 (dua) Sub Strategi yaitu 1) Sub Strategi WO-3; 2) Sub Strategi WO-2. Perspektif finansial terdiri dari 2 (dua) Sub Strategi yaitu 1) Sub Strategi SO-2; 2) Sub Strategi ST-2. Perspektif Learning \& Growth (L\&G) terdiri dari 3 (tiga) Sub strategi, yaitu 1) Sub Strategi SO-3; 2) Sub Strategi WO-1; 3) Sub Strategi WT-1. Perspektif Customer terdiri dari 3 (tiga) Sub strategi yaitu 1) Sub Strategi ST-3; 2) Sub Strategi SO-1; 3) Sub Strategi ST-1.

Pada penelitian selanjutnya dapat ditambahkan analisis sensitivitas dalam pengembangan strategi kebijakan komoditas pangan menuju ketahanan pangan nasional. Pada penelitian selanjutnya dapat ditambahkan analisis sustainabilitas atau keberlanjutan pada kebijakan ketahanan pangan nasional.

\section{DAFTAR PUSTAKA}

Alshaher, A. A. F. (2013). The McKinsey 7S model framework for e-learning system readiness assessment. International Journal of Advances in Engineering \& Technology, 6(5), 1948.

Baroto, M. B., Arvand, N., \& Ahmad, F. S. (2014). Effective strategy implementation. Journal of Advanced Management Science Volume, 2(1), 50-54. 
Czajkowska, A. (2016). SWOT analysis application for indications of the strategy action chosen enterprise in the construction sector. Production Engineering Archives, 10(1), 33-37.

Gupta, G., Mishra, R. P. \& Mundra, N., (2018). Development of a Framework for Reliability Centered Maintenance. Bandung, IEOM Society International, pp. 2383-2391.

Iranzadeh, S., Nojehdeh, S. H. \& Emami, N. N., (2017). The Impact of the Implication of Balanced Scorecard Model (BSC) in Performance of the Post Company. Problems and Perspectives in Management, 15(4), pp. 188-196.

Jafari, M., Shahanaghi, K. \& Tootooni, M., (2015). Developing a Robust Strategy Map in Balanced Scorecard Model Using Scenario Planning. Mathematical Problems in Engineering, pp. 1-9. Jayakhrishnan, M., Mohammad, A. K. b. \& Yusof, M. b. M., (2018). The Holistic View of Bussiness Intelligent (BI) and Big Data Analysis (BDA) toward Designing Strategic Performance Management Framework: A Case Study. Journal of Theoretical and Applied Information Technology, 96(7), pp. 2025-2045.

Nikolića, D. et al., (2015). SWOT - AHP Model For Prioritzation of Strategies of The Resort Stara Planina. Serbian Journal of Management, 10(2), pp. $141-150$.

Njeru, W. G., Awino, Z. B. \& Adwet, K., (2017). Strategy Implementation: Mckinsey's 7s Framework Configuration And Performance Of Large Supermarkets In Nairobi, Kenya. Archives of Business Research, 5(6), pp. 1-17.

Panackal, N. \& Singh, A., (2016). Using Interpretative Structural Modeling to Determine the Relation between Youth and Sustainable Rural Development. Journal of Management and Research, 4(1), pp. 58-64.

Rahmat, A. B. \& Ibrahim, C. K. I. C., (2018). Improving Multi-Organizational Team Integration using
Organizational Strategies. Paris, Proceedings of the International Conference on Industrial Engineering and Operations Management.

Rizal, M. et al., (2016). Institutional development strategy through Interpretive Structural Modelling (ISM) for gillnet fisher group in Barsela Aceh, Indonesia. AACL Bioflux, 9(4), pp. 802-814.

Roy, S. \& Misra, S., (2016). Interpretative Structural Modeling (ISM) of Tratvel and Tourism Enablres. Specialty Journal of Psychology and Management, 2(2), pp. 32-45.

Saad, R. I. \& Daraghma, Z., (2016). Using of the Balanced Scorecard for Performance Evaluation: Empirical Evidence from the Listed Corporations in the Palestine Exchange (PEX). International Journal of Business and Management, 11(3), pp. 215-222.

Shiri, S., Anvari, A. \& Soltani, H., (2014). An Assessment of Readiness Factors for Implementing ERP Based on Agility (Extension of Mckinsey 7s Model). International Journal of Management, Accounting and Economics, 3(1), pp. 229-246.

Suharno, M.M., Gunawan, K., (2019), The management revolution of Indonesian agriculture towards national food resilience, International Journal of Scientific and Technology Research, 8(11), pp. 2140-2151

Zadeh, M. A., Aleagha, M. M. \& Nia, A. B., (2018). The Development of a Cleaner Production Model and Applied Management Solutions for the Pharmaceutical Industry. Eurasian Journal of Analytical Chemistry, 13(3), pp. 1-9.

Živković, Ž., Nikolić, D., Djordjević, P. \& Ivan Mihajlović, M. S., (2015). Analytical Network Process in the Framework of SWOT Analysis for Strategic Decision Making (Case Study: Technical Faculty in Bor, University of Belgrade, Serbia). Acta Polytechnica Hungarica, 12(7), pp. 199-216. 